\title{
FATAL INTERACTION OF MARBLED GODWIT WITH RIBBED MUSSEL
}

\author{
HIRAM RAFAEL MORENO-HIGAREDA, Pro Esteros, A.C. Departamento de \\ Investigación, Calle Cuarta 210, Zona Centro, C.P. 22800, Ensenada, Baja California, \\ México; moreno.hiram@uabc.edu.mx
}

ERNESTO CAMPOS and GORGONIO RUIZ-CAMPOS, Facultad de Ciencias, Universidad Autónoma de Baja California, Carretera Ensenada-Tijuana No. 3917, Colonia Playitas, C.P. 22860, Ensenada, Baja California, México

HORACIO DE LA CUEVA, Departamento de Biología de la Conservación, Centro de Investigación Científica y de Educación Superior de Ensenada, Baja California. Carretera Ensenada-Tijuana No. 3918, Pedregal Playitas, C.P. 22860, Ensenada, Baja California, México; cuevas@cicese.mx (corresponding author)

The Marbled Godwit (Limosa fedoa) is a large shorebird that breeds in the grasslands of the north-central United States and south-central Canada, with small and isolated nesting populations along the southwest shore of James Bay, Canada, and on the Alaska Peninsula (Gratto-Trevor 2000). It migrates principally to the west coast of North America, wintering mainly from Washington to El Salvador, including the Baja California Peninsula (Gratto-Trevor 2000). Independently of any annual variation in numbers, the Marbled Godwit is common at Estero Punta Banda, with numbers estimated from many hundred (Jiménez et al. 2009) to nearly 2500 (Palacios et al. 1991) individuals.

On 9 August 2018, during a rising tide at 14:00, we discovered a dying Marbled Godwit (Limosa fedoa) in the main tidal channel at Estero Punta Banda (31 45' 29" $\left.\mathrm{N} 116^{\circ} 37^{\prime} 13^{\prime \prime} \mathrm{W}\right)$. The right leg of the bird was trapped between the valves of a live Ribbed Mussel (Geukensia demissa) approximately $10 \mathrm{~cm}$ long. The bird was soaking wet, emaciated, and breathing with difficulty, with water coming out of its lungs. After it died (Figure 1), we found that the innermost toe on the godwit's right leg was broken and nearly amputated by the grip of the mussel. Under similar circumstances, Moreno et al. (2019) recorded two dead chicks of the Light-footed Ridgway's Rail (Rallus obsoletus levipes) in the same area. Rails with Ribbed Mussels clamped to their toes have been recorded, as well as rails without toes, suggesting mutilation by the mussel (reviewed by Nestlerode 2009). Similar but not fatal interactions between Bar-tailed Godwits (Limosa lapponica) and clams have been observed in coastal China by Melville and Choi (2013), who also tabulated records of bird species with bivalves attached to the bill or foot.

Geukensia demissa is native to the Atlantic coast of the USA, where its densities range from 1164 to 10,000 individuals $/ \mathrm{m}^{2}$ (Nielsen and Franz 1995, Chintala et al. 2006). The densities at Estero Punta Banda are three to four orders of magnitude lower than those in its native range, ranging from 3.5 to 35 individuals $/ \mathrm{m}^{2}$ (Torchin et al. 2005, Moreno et al. 2019).

Torchin et al. (2005) described the Ribbed Mussel as an exotic and invasive species, associated with California cordgrass (Spartina foliosa) on the coast of California and northwestern Baja California.

Gratto-Trevor (2000) pointed out the dearth of knowledge of factors affecting survival of adult Marbled Godwits. At least at Punta Banda and other sites where the Ribbed Mussel occurs as an invasive species, this type of interaction is a risk factor for the godwit and other birds. Study of the spatial distribution and density of the Ribbed Mussel and its interactions with other species, as documented by Nestlerode (2009) and Melvile and Choi (2013), is warranted. Gratto-Trevor (2000) did not list the mussel among the godwit's major foods, though its diet includes some bivalves of similar size. But Moffitt (1941) found the Ribbed Mussel to be the leading food of Ridgway's Rail in San Francisco Bay. So the mussel's role as food source as well as a threat to birds should be evaluated before any eradication from Estero Punta Banda is considered. 


\section{NOTES}

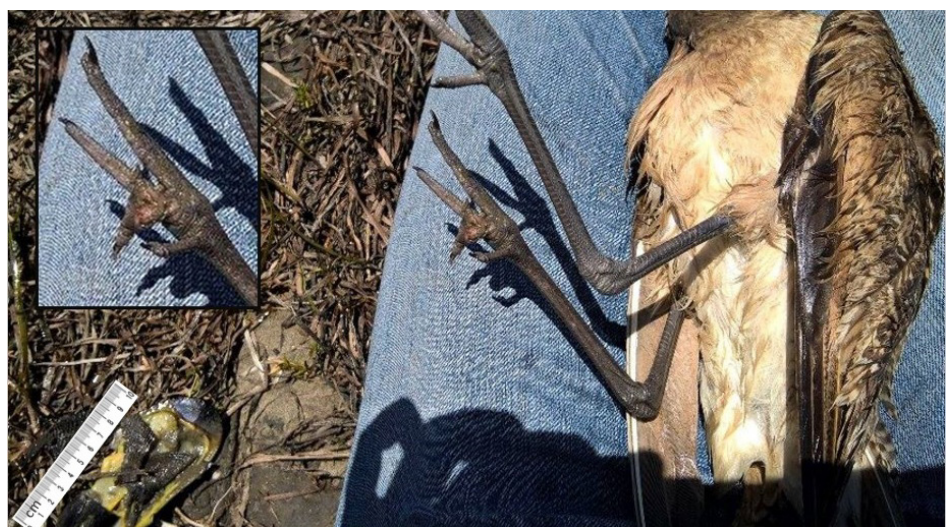

Figure 1. A Marbled Godwit (Limosa fedoa) with toe almost amputated by the Ribbed Mussel (Geukensia demissa) seen on left. Ruler, $10 \mathrm{~cm}$.

Photo by Hiram Rafael Moreno-Higareda

We thank D. D. Gibson and D. R. Ruthrauff for their excellent suggestions.

\section{LITERATURE CITED}

Chintala, M. C., Wigand, C., and Thursby, G. 2006. Comparison of Geukensia demissa populations in Rhode Island fringe salt marshes with varying nitrogen loads. Mar. Ecol. Prog. Ser. 320:101-108; doi 10.3354/meps320101.

Gratto-Trevor, C. L. 2000. Marbled Godwit (Limosa fedoa), in The Birds of North America (A. F. Poole and F. B. Gill, eds.), no 492. Birds N. Am., Inc., Philadelphia; doi $10.2173 /$ bna.492.

Jiménez Pérez, L. C., de la Cueva, H., Molina-Peralta, F., and Estrada-Ramírez, A. 2009. Avifauna del estero de Punta Banda, Baja California, México. Acta Zool. Mex. 25:589-608; doi 10.21829/azm.2009.253663.

Melville, D. S., and Choi, C.-Y. 2013. Reactions of Bar-tailed Godwits Limosa lapponica to apparent capture by clams. Wader Study Group Bull. 120:205-207.

Moffitt, J. 1941. Notes on the food of the California Clapper Rail. Condor 43:270273; doi 10.2307/1364288.

Moreno-Higareda, H. R., Campos, E., de la Cueva, H., García-Zárate, M. A., and Martínez-Ríos Del Río, L. 2019. ¿Amenaza un bivalvo exótico al rascón picudo en Baja California? Huitzil 20(2):e-531; doi 10.28947/hrmo.2019.20.2.454.

Nestlerode, M. 2009. Geukensia demissa. Animal diversity web; www.animaldiversity. org/accounts/Geukensia_demissa (28 August 2019).

Nielsen, K., and Franz, D. 1995. The influence of adult conspecifics and shore level on recruitment of the ribbed mussel Geukensia demissa (Dillwyn) in Jamaica Bay, N.Y. J. Exp. Mar. Biol. Ecol. 188:89-98; doi 10.1016/0022-0981(94)00190-O.

Palacios, E., Escofet, A., and Loya-Salinas, D. H. 1991. The Estero de Punta Banda, BC, Mexico as a link in the Pacific Flyway: Abundance of shorebirds. Cienc. Mar. 17:109-131; doi 10.7773/cm.v17i3.814

Torchin, M. E., Hechinger, R. F., Huspeni, T. C., Whitney, K. L., and Lafferty, K. D. 2005. The introduced ribbed mussel (Geukensia demissa) in Estero de Punta Banda, Mexico: Interactions with the native cordgrass, Spartina foliosa. Biol. Invasions 7:607-614; doi 10.1007/s10530-004-5851-5. 